Correction

\title{
Correction: Sioud et al. Evaluation of In Vitro Phototoxicity of a Minibody-IR700 Conjugate Using Cell Monolayer and Multicellular Tumor Spheroid Models. Cancers 2021, 13, 3356
}

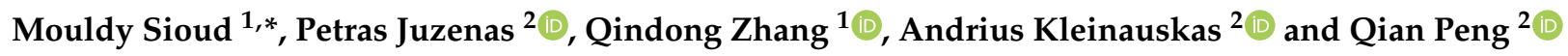 \\ 1 Division of Cancer Medicine, Department of Cancer Immunology, Oslo University Hospital, University of \\ Oslo, Ullernchausseen 70, 0379 Oslo, Norway; Qindong.Zhang@rr-research.no \\ 2 Division of Laboratory Medicine, Department of Pathology, Oslo University Hospital-Radiumhospitalet, \\ Ullernchausseen 70, 0379 Oslo, Norway; Petras.Juzenas@rr-research.no (P.J.); \\ Andrius.Kleinauskas@rr-research.no (A.K.); Qian.Peng@rr-research.no (Q.P.) \\ * Correspondence: Mouldy.Sioud@rr-research.no
}

check for

updates

Citation: Sioud, M.; Juzenas, P.; Zhang, Q.; Kleinauskas, A.; Peng, Q. Correction: Sioud et al. Evaluation of In Vitro Phototoxicity of a Minibody-IR700 Conjugate Using Cell Monolayer and Multicellular Tumor Spheroid Models. Cancers 2021, 13, 3356. Cancers 2021, 13, 5513. https://doi.org/10.3390/cancers 13215513

Received: 6 August 2021

Accepted: 14 October 2021

Published: 3 November 2021

Publisher's Note: MDPI stays neutral with regard to jurisdictional claims in published maps and institutional affiliations.

Copyright: (C) 2021 by the authors Licensee MDPI, Basel, Switzerland. This article is an open access article distributed under the terms and conditions of the Creative Commons Attribution (CC BY) license (https:// creativecommons.org/licenses/by/ $4.0 /)$.
The authors wish to make the following corrections to this paper [1]: In the original article, there was an error in Figure 4. The control panel (BF, FDA, and PI) was erroneously duplicated during the final figure assembly, resulting in two identical panels (control and IR700). The corrected Figure 4 appears below.
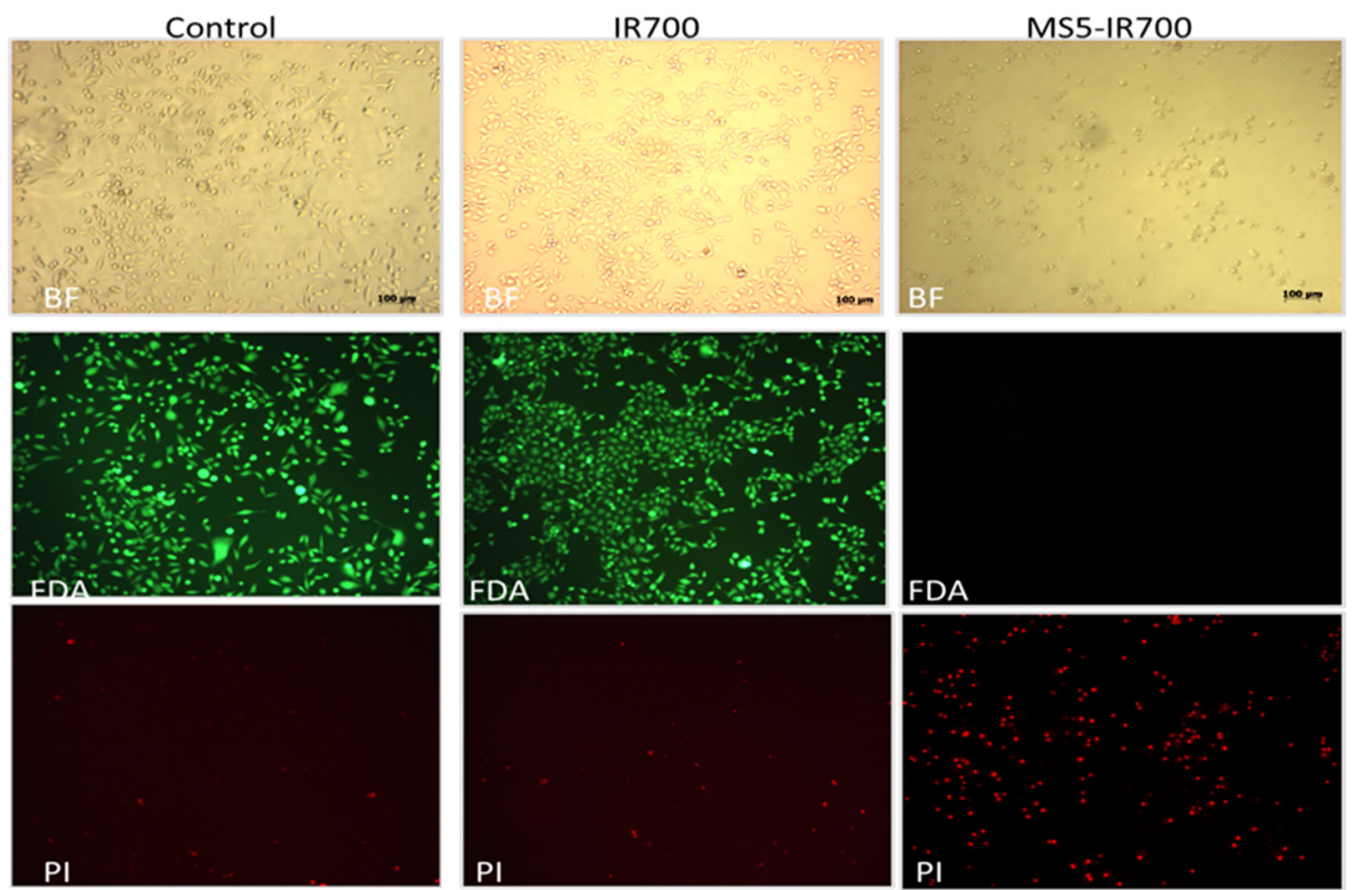

The authors apologize for any inconvenience caused and state that the scientific conclusions are unaffected. The original article has been updated.

\section{Reference}

1. Sioud, M.; Juzenas, P.; Zhang, Q.; Kleinauskas, A.; Peng, Q. Evaluation of In Vitro Phototoxicity of a Minibody-IR700 Conjugate Using Cell Monolayer and Multicellular Tumor Spheroid Models. Cancers 2021, 13, 3356. [CrossRef] [PubMed] 